\title{
SPINEL CHEMISTRY AS AN INDICATOR OF CRYSTAL FRACTIONATION AND LIQUID IMMISCIBILITY IN THE TAPIRA ALKALINE-CARBONATITE COMPLEX, MINAS GERAIS, BRAZIL
}

\author{
José Affonso Brod ${ }^{1,2}$, José Carlos Gaspar ${ }^{1,2}$, Henrique Senna Diniz-Pinto ${ }^{1,2}$, Tereza Cristina \\ Junqueira-Brod ${ }^{\mathbf{1}, 2}$ \\ ${ }^{1}$ Universidade de Brasília, Brazil, ${ }^{2}$ CNPq, Brazil
}

\section{INTRODUCTION}

The Tapira complex is located in the western portion of Minas Gerais State, SE Brazil, $30 \mathrm{~km}$ south-southeast of the city of Araxá, forming part of the LateCretaceous Alto Paranaíba Igneous Province (APIP, Gibson et al., 1995). The complex intrudes phyllites, schists and quartzites of the Late-Proterozoic Brasília mobile belt, adjacent to the São Francisco craton.

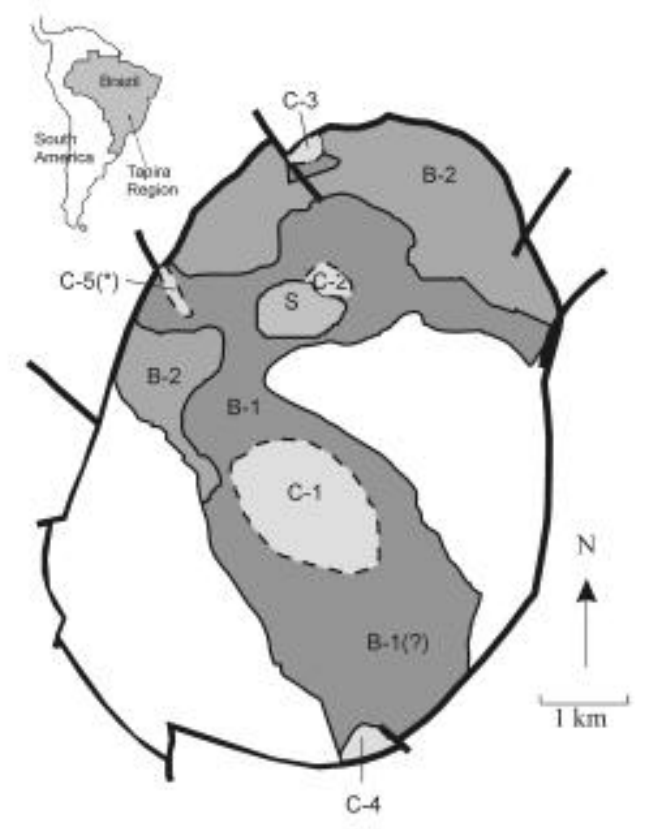

Figure 1: Geological sketch of the Tapira complex (After Brod, 1999).

\section{GEOLOGY OF THE TAPIRA COMPLEX}

The Complex is roughly elliptical (Figure 1), formed by the amalgamation of several intrusions of plutonic silicate rocks and less voluminous carbonatites.

The silicate plutonic-rock series (SPS) consists mainly of bebedourite (a variety of alkaline clinopyroxenite), with subordinate wehrlite and syenite, and rare melilitolite and dunite. Two units of ultramafic rocks are recognised. The $\mathrm{B} 1$ unit occupies most of the central portion of the complex, partly surrounded by B2 in the north. Coarse- to medium-grained syenites occur as an intrusion in the northern part of the complex, and as smaller plugs elsewhere.

Five episodes of carbonatitee activity were identified. The earliest and largest carbonatite (C1) intrudes B1 in the centre of the complex. $\mathrm{C} 2$ carbonatites are spatially associated with syenites, in the northern part of the complex, but also occur as scattered dykes and diatreme-facies breccias elsewhere. C3 and C4 are small sövite intrusions, respectively near the northern and southern margins of the complex. C5 forms widespread late-stage dykes and veinlets. A progression in composition is observed, starting with dolomitebearing sövites $(\mathrm{C} 1, \mathrm{C} 2)$ and evolving towards pure sövite (C3, C4). Dolomite-rich carbonatites are recurrent in the late-stage $\mathrm{C} 5$ dykes.

All plutonic rock-types are crosscut by fine-grained ultramafic dykes. These are carbonate-rich and may contain carbonate ocelli, indicating that immiscibility of carbonatite liquid occurred early in the evolution of the complex (Brod, 1999) The most primitive dyke-rocks have been named phlogopite picrites (Gibson et al, 1995), and consist of olivine phenocrysts in a groundmass of phlogopite, carbonate, perovskite, oxides and apatite. Dykes of a second variety typically lack olivine and $\mathrm{Cr}$-rich spinel, and are compositionally similar to the SPS bebedourites, representing slightly evolved liquids. These are referred to here as bebedouritic dykes. The primitive Tapira magmas are ultrapotassic and have strong kamafugitic affinity (Brod et al., 2000).

\section{SPINEL CHEMISTRY}

Primary magmatic opaque minerals present in Tapira rocks comprise mainly chromite and magnetite, with rare ilmenite. Magnetite is by far the most abundant species, occurring in both carbonatites and silicate 
rocks. Cr-rich (up to 9.3 atoms p.f.u) spinels are restricted to phlogopite picrites and, occasionally, to wehrlites.

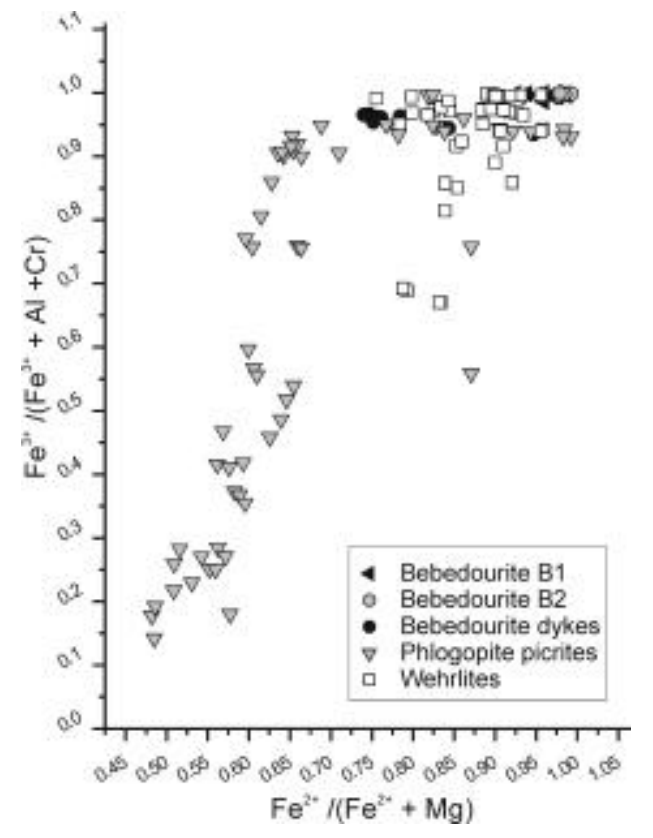

Figure 2: $\mathrm{Fe}^{2+} /\left(\mathrm{Fe}^{2+}+\mathrm{Mg}\right)$ ratio plotted against $\mathrm{Fe}^{3+} /\left(\mathrm{Fe}^{3+}+\right.$ $\mathrm{Al}+\mathrm{Cr}$ ) for spinels from Tapira silicate rocks.

Figure 2 shows that spinels from phlogopite picrites and bebedouritic dykes start from $\mathrm{Cr}$ - (and Al-) rich compositions and evolve through relative increase in $\mathrm{Fe}^{3+}$, reflecting progressive enrichment in the magnetite end-member. $\mathrm{A}$ rapid decrease in $\mathrm{Cr}$ and $\mathrm{Al}$, and increase of $\mathrm{Fe}^{3+}$ occurs within a comparatively short range $(0.5$ to 0.7$)$ of the $\mathrm{Fe}^{2+} /\left(\mathrm{Fe}^{2+}+\mathrm{Mg}\right)$ ratio. For $\mathrm{Fe}^{2+} /\left(\mathrm{Fe}^{2+}+\mathrm{Mg}\right)$ higher than 0.7 , spinels in phlogopite picrites and bebedouritic dykes contain very little of both $\mathrm{Cr}$ and $\mathrm{Al}$, and their compositional evolution becomes insensitive to the $\mathrm{Fe}^{3+} /\left(\mathrm{Fe}^{3+}+\mathrm{Al}+\mathrm{Cr}\right)$ ratio. However, a few samples seem to follow a trend of steady increase in both ratios in Figure 2, progressing directly to the magnetite component. This trend seems to coincide with the alignment of some spinel analyses from wehrlites.

Figure 3 shows that, in terms of trivalent elements, spinels from the Tapira silicate rocks may be divided in at least three separate trends. Phlogopite picrites evolve initially from $\mathrm{Cr}$-rich to $\mathrm{Cr}$-poor, at relatively constant $\mathrm{Al}$ content. Only after most of the $\mathrm{Cr}$ is consumed in the crystallising liquid, $\mathrm{Al}$ content in these spinels starts to decrease, at constantly low $\mathrm{Cr}$ levels. A second trend may be defined by spinels from bebedourites and bebedouritic dykes, which evolve by Al decrease and $\mathrm{Fe}^{3+}$ increase, and are virtually $\mathrm{Cr}$-free throughout.
They thus correspond roughly to the second part of the phlogopite picrite trend, but at even lower $\mathrm{Cr}$, and are plotted together with the phlogopite picrites in the lefthand side diagram of Figure 3. A third group of analyses comprises spinels from wehrlites, which evolve through $\mathrm{Cr}$ decrease and $\mathrm{Fe}^{3+}$ increase at typically low Al levels.

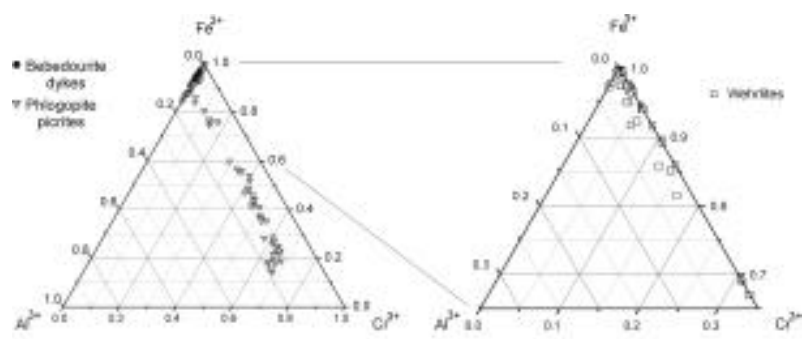

Figure 3 : $\mathrm{Fe}^{3+}-\mathrm{Al}-\mathrm{Cr}$ diagram showing the evolution trends of spinels from Tapira silicate rocks. Left $=$ spinels from phlogopite picrites and bebedouritic dykes; right $=$ spinels from wehrlites.

The most striking feature of this diagram is that spinels from the phlogopite picrites and bebedouritic dykes may fit into a single evolving trend of decreasing $\mathrm{Cr}$ (at first), and then $\mathrm{Al}$, coupled with increasing $\mathrm{Fe} 3+$. On the other hand, wehrlite spinels are difficult to reconcile with this trend, since they reach the magnetite endmember from the opposite side of the diagram (i.e. $\mathrm{Cr}$ decreases and $\mathrm{Fe}^{3+}$ increases at low $\mathrm{Al}$ content). Spinels from bebedourite and carbonatite are not plotted, since they cluster near the $\mathrm{Fe}^{3+}$ apex and are not visible on the adopted scale.

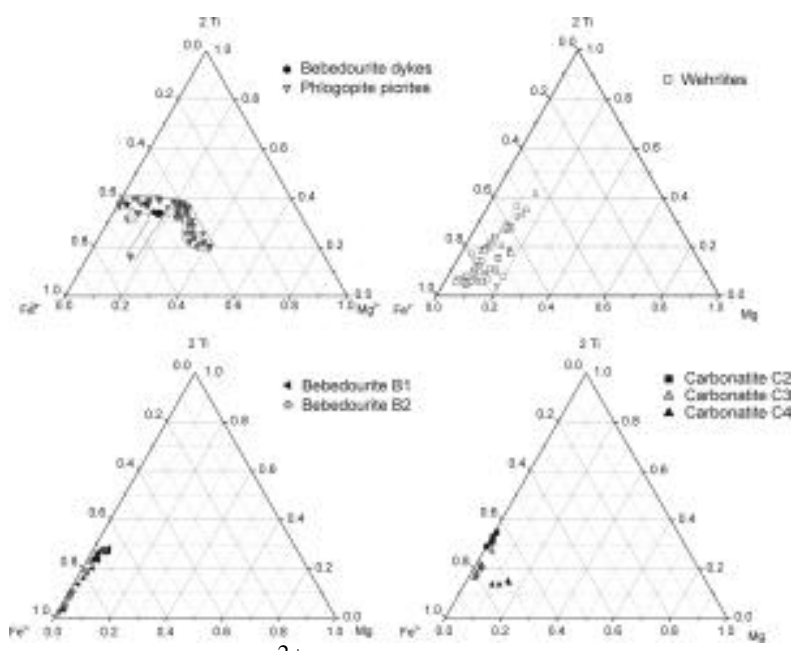

Figure 4: - $\mathrm{Ti}_{-}-\mathrm{Fe}^{2+}-\mathrm{Mg}$ plot of spinels from Tapira silicate rocks and carbonatites.

The diagrams in Figure 4 show the evolution of Tapira spinels in terms of $\mathrm{Ti}, \mathrm{Fe}^{2+}$ and $\mathrm{Mg}$ for silicate rocks. Noteworthy features are a sudden Ti increase near the 
beginning of the trend of phlogopite picrite spinels, and the good agreement between the trends of phlogopite picrites and bebedouritic dykes. Spinels from the wehrlites follow an independent trend of continuously decreasing $\mathrm{Ti}$ and $\mathrm{Mg}$, and increasing $\mathrm{Fe}^{3+}$. Spinels from B1 and B2 bebedourites vary in the same direction as those from wehrlite, but at lower $\mathrm{Mg}$ content, and spinels from B1 bebedourites are less evolved than those from B2. Spinels from C2, C3 and C4 carbonatites show progressively lower $\mathrm{Ti}$, in this sequence, but $\mathrm{C} 4$ is shifted from this trend toward slightly higher $\mathrm{Mg}$ contents.

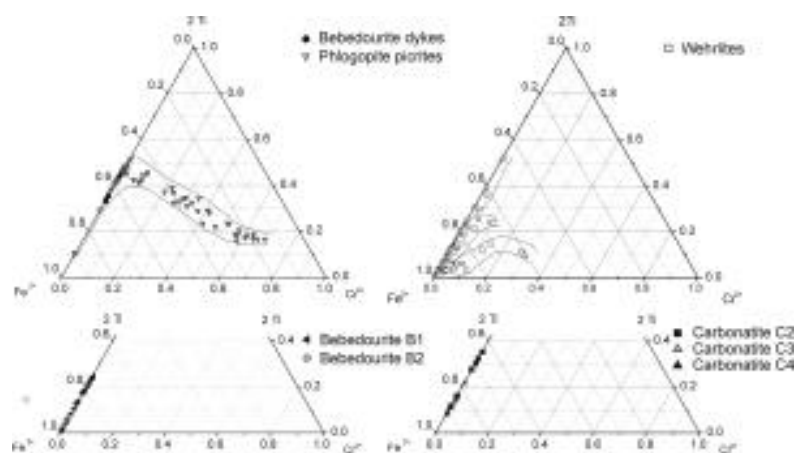

Figure 5: $\mathrm{Ti}-\mathrm{Cr}-\mathrm{Fe} 3+$ plots of Tapira spinels. Note the multiple evolution trends of wehrlite spinels, and their $\mathrm{Cr}$ depleted character, relatively to the most unevolved phlogopite picrite spinels.

Plots in Figure 5 relate $\mathrm{Ti}, \mathrm{Fe}^{3+}$ and $\mathrm{Cr}$ for spinels of various Tapira rock-types. Here, phlogopite picrite spinels follow a trend of decreasing $\mathrm{Cr}$ at relatively constant proportions of the magnetite and ulvöspinel end-members. When all $\mathrm{Cr}$ is consumed in crystallising liquid, they evolve by decreasing $\mathrm{Ti}$ (ulvöspinel endmember) and increasing $\mathrm{Fe}^{3+}$ (magnetite end-member). All analyses of spinels from bebedouritic dykes plot after this inflection towards magnetite.

Wehrlite spinels appear to follow multiple evolution trends, in some respect similar to the general evolution of the dykes, but at a much lower Ti level. Also, and perhaps more importantly, all wehrlitic trends start at considerably lower $\mathrm{Cr}$ than the phlogopite picrite trend. This has important bearings on the petrogenetic evolution of the complex. In the absence of expressive dunite accumulations, wehrlites would be the firstchoice candidate, among Tapira rocks, to represent unevolved cumulates produced by fractional crystallisation of the phlogopite picrite magma. However, if this was to be the case, one would expect much higher $\mathrm{Cr}$ contents in the spinels from wehrlites.
The features depicted in Figure 5 suggest that neither the phlogopite picrites nor the bebedouritic dykes can be related to the wehrlites through fractional crystallisation, as far as spinel chemistry is concerned. Instead, there must be Cr-rich dunites accumulated elsewhere. Perhaps these cumulates are located at a lower, unexposed level of the complex or, alternatively, trapped in an independent, fractionating magma chamber at depth. Field, petrographic, mineralogical and whole-rock geochemical evidence discussed elsewhere (Brod, 1999) indicate that the second alternative is more likely to represent the geological situation of the Tapira complex. Spinels from bebedourites and carbonatites are $\mathrm{Cr}$-free and plot along the $\mathrm{Ti}-\mathrm{Fe}^{3+}$ side of the diagram.

Figure 6 demonstrates the two-step evolution of Tapira spinels. Taking into account the $\mathrm{Cr}$ and $\mathrm{Al}$ variation described in previous diagrams, this can be explained in terms of initial increase in the magnetite and ulvöspinel components at the expense of $\mathrm{Cr}$ - and $\mathrm{Al}$-spinel endmembers, followed, after a sharp inflection, by enrichment in magnetite at the expense of ulvöspinel. It is noteworthy the difference between the phlogopite picrite trend and the multiple-trend evolution of the wehrlite spinels. Carbonatite spinels seem to evolve in the sequence $\mathrm{C} 2$ to $\mathrm{C} 3$ to $\mathrm{C} 4$, becoming progressively enriched in the magnetite molecule and depleted in Ti. Analyses of $\mathrm{C} 1$ are not plotted, as petrographic evidence indicates that they underwent extensive subsolidus transformation. However, the presence of ilmenite lamellae exsolved from these spinels suggests that their original $\mathrm{Ti}$ content was relatively high, perhaps plotting to the right-hand side of $\mathrm{C} 2$ in the diagram. The plot for bebedourites confirms the more evolved character of $\mathrm{B} 2$ rocks, relatively to $\mathrm{B} 1$.

\section{DISCUSSION}

Spinel-group minerals show a wide compositional variation in the different Tapira rock-types. As a general rule, spinels in the least differentiated rocks (phlogopite picrites) are chromite, and evolve, with magma differentiation, to $\mathrm{Cr}-, \mathrm{Al}-$ poor and $\mathrm{Fe}^{3+}-$, Tirich spinel, by progressive and simultaneous increase in the magnetite and ulvöspinel contents. When $\mathrm{Cr}$ and $\mathrm{Al}$ become unavailable, spinel evolution shifts towards pure magnetite, at the expense of the ulvöspinel component.

The observed increase in the $\mathrm{Fe}^{2+} /\left(\mathrm{Fe}^{2+}+\mathrm{Mg}\right)$ ratio with differentiation is consistent with spinel evolution in other examples of alkaline rocks and carbonatites (e.g. 

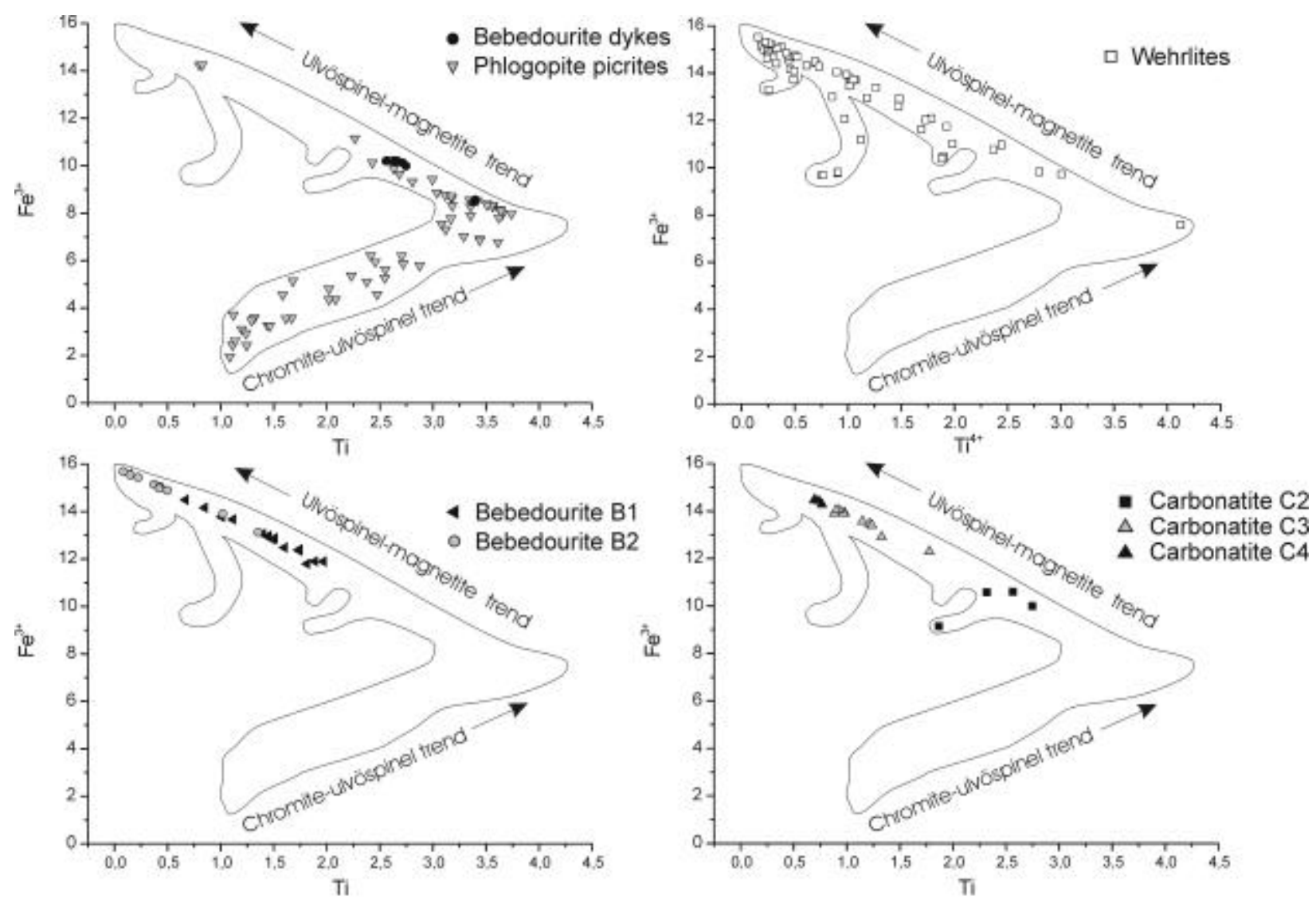

Figure 6: Ti-Fe ${ }^{7+}$ plot showing the chromite-ulvöspinel and ulvöspinel-magnetite steps of the spinel evolution at Tapira. Top-left = phlogopite picrites and bebedouritic dykes; Top-right $=$ wehrlites; Bottom-left = bebedourites; Bottom-right $=$ carbonatites. Outlined area encompasses all analyses. Note the multi-stage evolution trends for wehrlite spinels.

Gaspar and Wyllie 1983, Mitchell and Bergman 1991, Mitchell, 1995).

Minor element contents of Tapira magnetites are also consistent with magmatic evolution of the host rock. Thus, magnetites from phlogopite picrites have the highest $\mathrm{TiO} 2$ (up to 16.8 wt. \%), $\mathrm{Al} 2 \mathrm{O} 3$ (up to 2.74 wt. $\%$ ), $\mathrm{MnO}$ (up to 2.76 wt. \%) and $\mathrm{MgO}$ (up to 9.95 wt. $\%$ ), whilst those in the SPS and carbonatites become progressively poorer in all minor elements, leading to compositions close to the ideal magnetite molecule.

\section{ORIGIN OF TAPIRA WEHRLITES}

Although the spinels from wehrlites do contain $\mathrm{Cr}$, they are depleted in the chromite end-member with respect to those in phlogopite picrites. Therefore, the wehrlites are unlikely to represent cumulates fractionated from phlogopite picrite magmas. On the other hand, the bebedouritic dykes are too evolved to fractionate neither olivine nor $\mathrm{Cr}$-rich spinel, which renders them equally unfit to originate the wehrlites.

One attractive alternative for the origin of the Tapira wehrlites is that they accumulated from an unevolved carbonatitic magma. If an immiscible carbonate liquid was to be able to fractionate olivine and Cr-bearing spinel to produce the Tapira wehrlites, the immiscibility event must have occurred at a very early stage, for the parental magma must have been ultramafic and $\mathrm{Cr}$-rich. Our unpublished data on the chemistry of olivine from carbonatite complexes (Gaspar et al., in preparation) suggest that olivines from Tapira wehrlites have carbonatitic affinity. In this case, the Tapira wehrlites would not be part of the same fractionation series as the bebedourites, as generally thought, but would be more closely related to other carbonatite-derived rocks, such as phoscorites and nelsonites.

One problem remains to be solved if the above model is to be accepted: According to Mitchell (1997), the high $\mathrm{Ti}$ solubility in carbonate magmas means that perovskite would be a late-stage crystallising phase in carbonatite, in contrast with its early formation in ultramafic alkaline rocks. This is difficult to reconcile with abundant cumulus $\mathrm{Ca}-\mathrm{Ti}$ perovskite contained in Tapira wehrlites, if they were to be fractionated from an unevolved carbonatite. 
Pressure and temperature constraints on perovskite stability in carbonatite liquids are still poorly known, but the preliminary data of Mitchell (1997) indicate that the first perovskite to be formed in the haplocarbonatite system, at $650^{\circ} \mathrm{C}$ and 1 atm will be $\mathrm{Ca}$ - and Ti-rich, evolving, at lower temperatures toward Na- and REEenrichment. The question, however, is not only when perovskite will start crystallising from a carbonatite liquid, but also whether there will be an adequate $\mathrm{Ti}$ supply, since $\mathrm{Ti}$ is known to partition strongly to the silicate immiscible liquid.

We suggest that, if the Tapira wehrlites are cumulates derived from an immiscible carbonate liquid, this immiscibility event must have occurred from a considerably unevolved ultramafic parent (e.g. phlogopite picrite), at high temperature, in order to explain the $\mathrm{Cr}$ content of wehrlite spinels. Furthermore, the immiscibility must have been incomplete, so that some $\mathrm{Si}$ and $\mathrm{Ti}$ remained in the carbonatite liquid in concentrations high enough to allow the precipitation of abundant silicate minerals (olivine, pyroxene, phlogopite) and Ca-Ti-perovskite. Brod (1999) demonstrated that the Tapira magmas underwent multiple-stage carbonate-silicate liquid immiscibility, and that evidence for immiscible carbonate appear early in the crystallisation history of phlogopite picrites, which is in good agreement with the evidence and interpretations presented here.

\section{MAGMATIC EVOLUTION OF BEBEDOURITES AND CARBONATITES}

Spinel from bebedourites, bebedouritic dykes, and carbonatites are virtually $\mathrm{Cr}$-free, evolving along the ulvöspinel-magnetite trend. In general, spinel chemistry indicates that $\mathrm{B} 2$ bebedourites are more evolved than $\mathrm{B} 1$, and that Tapira carbonatites evolved in the sequence $(\mathrm{C} 1$ ?) to $\mathrm{C} 2$ to $\mathrm{C} 3$ to $\mathrm{C} 4$, which agrees with field and other mineral chemistry and whole-rock chemistry evidence (Brod, 1999, Brod et al., 2001).

From B1 to B2 bebedourites, spinel evolution is marked by progressive depletion in $\mathrm{TiO} 2$ and $\mathrm{MgO}$, coupled with an increase in total iron and in the estimated $\mathrm{Fe} 2 \mathrm{O} 3$, but not necessarily in the estimated $\mathrm{FeO}$ contents. Manganese does not vary systematically between different SPS rock groups. Carbonatite magnetites vary within a restricted range, reflecting extreme depletion in both $\mathrm{Cr}$ and $\mathrm{Al}$, and stronger progressive depletion in $\mathrm{Ti}$, when compared with the magnetites from the SPS.

\section{ACKNOWLEDGEMENTS}

The Universities of Brasília (Brazil) and Cambridge (UK) are gratefully acknowledged for access to their microprobe facilities. The authors with to thank CNPq Brazilian National Council for Research and Development for research grants to JAB, JCG, and HSDP, and a Ph.D. grant to TCJB.

\section{REFERENCES}

Brod, J.A., 1999. Petrology and geochemistry of the Tapira alkaline complex, Minas Gerais State, Brazil. Ph.D. Thesis, University of Durham, UK.

Brod, J.A., Gaspar, J.C., Araújo, D.P., Gibson, S.A., Thompson, R.N., Junqueira-Brod, T.C., 2001. Phlogopite and tetra-ferriphlogopite from Brazilian carbonatite complexes: petrogenetic constraints and implication for mineral-chemistry systematics. J. Asian Earth Sci., 19: 265-296

Brod J.A., Gibson S.A., Thompson, R.N., Junqueira-Brod T.C., Seer H.J., Moraes, L.C., Boaventura G.R.. 2000. The kamafugite-carbonatite association in the Alto Paranaíba Igneous Province, southeastern Brazil. Revista Brasileira de Geociências. 30:404-408

Gaspar, J.C., Wyllie, P.J., 1983. Magnetite in the carbonatites from the Jacupiranga complex, Brazil. Am. Mineral., 68:195-213.

Gibson, S.A., Thompson, R.N., Leonardos, O.H., Dickin, A.P., Mitchell, J.G., 1995. The Late Cretaceous impact of the Trindade mantle plume - evidence from large-volume, mafic, potassic magmatism in SE Brazil. J. Petrol., 36: 189-229

Mitchell, R.H., 1995. Kimberlites, orangeites and related rocks. Plenum Press, New York.

Mitchell, R.H., 1997. Preliminary studies of the solubility and stability of perovskite group compounds in the synthetic carbonatite system calcite-portlandite. J. African Earth Sci., 25:147-158.

Mitchell, R.H., Bergman, S.C., 1991. Petrology of Lamproites. Plenum Press, New York

Contact: J. A. Brod, Universidade de Brasília, Instituto de Geociências, Brasília, DF, Brazil. 70.910-900. E-mail:

brod@unb.br 